Pobrane z czasopisma Annales H - Oeconomia http://oeconomia.annales.umcs.pl Data: 26/04/2023 13:36:29

DOI:10.17951/h.2017.51.2.177

\begin{tabular}{lcc}
\hline \multicolumn{1}{c}{ A N N A L E S } \\
UNIVERSITATIS & MARIAE CURIE-SKŁODOWSKA \\
LUBLIN - POLONIA & \\
VOL. LI, 2 & SECTIOH H \\
\hline
\end{tabular}

University of Economics in Katowice, Department of Consumption Research

JUSTYNA MATYSIEWICZ

justyna.matysiewicz@ue.katowice.pl

\title{
Value Co-Creation in Health Care Networks - International Perspective
}

Współtworzenie wartości dla pacjenta w sieciowych jednostkach medycznych

- perspektywa międzynarodowa

Key words: marketing; value co-creation; value-creating system; health care

Słowa kluczowe: marketing; współtworzenie wartości; system tworzenia wartości; ochrona zdrowia

JEL codes: M31; I1

\section{Introduction}

Well-developed economies are characterized by the interaction of two important trends: an increased role of services in the economy, and an increased role of knowledge in the technological and social innovation development process. As well as the development of the services sector, a new type of services has emerged: professional services. Professional services are based on knowledge and expertise of a professional [Helander and Hirvonen 2001].

Essential to any business networks, especially for knowledge base one, is the underlying system through which it produces the value. This value-system construct is based on the notion that each product/service requires a set of value creating activities performed by a number of actors forming a value-creating system [Möller and Rajala 2007, pp. 895-908]. A value-creating system is a set of activities that create value for consumers [Parolini 1999]. Various resources are used in carrying out these activities, linked by various kinds of flows. Value-creating systems contain several 
economic actors who may be involved in more than one value-creating system. Within the value net model, economic activity is thought of not in terms of a set of economic actors who internally perform a set of activities, but as a set of activities that create value for final customers [Parolini 1999].

The issues addressed in the article focuses on marketing activities of health care services networks in the context of value co-creation. The aim of the study is identification and description of the process of value co-creation in health care networks.

\section{Value-creation system}

Marketing is about managing profitable customer relationships. The twofold goal of marketing is to attract new customers by promising superior value and to keep and grow current customers by delivering satisfaction [Armstrong and Kotler 2007]. Creating value for customers has been recognized as a key concept in marketing [Sheth et al. 1991; Rust and Oliver 1994; Drucker 1954], making the value and value creation an important research subject [Grönroos 2001, pp. 240-247]. At the general level, the customer value has been referred to as an overall assessment [Zeithaml 1988 pp. 2-22], a function of consumption behavior [Sheth et al. 1991], perceived quality adjusted for the relative price [Gale 1998], emotional bond [Butz and Goodstein 1996, pp. 63-77], relationship, personal perception [Woodall 2003], and subjective personal introspection [Holbrook 2005, pp. 45-61]. In the article it is assumed that value for customers means that, after being assisted by the provision of resources or interactive processes, customers are or feel better off than before [Grönroos 2001, pp. 240-247]. Features of health care services quite considerably contribute to their distinctive character and, at the same time, affect the value offered to the customer/patient. On the basis of their skills and knowledge and with full observance of norms and rules prevailing in a health care services area, medical services firms provide services which are designed to solve problems of their customers. Customers' participation is vital and indispensable for this cooperation [Bitner et al. 1997].

The fundamental idea in the value creation approach is that by knowing the customer's value creation process the provider can better identify the problems that the customer has concerning his business activities. In fact, the provider can even notice those problems and concerns that the customer himself cannot see [Allee 2008, pp. 5-24]. By providing a solution to these problems the provider can offer a more valuable relationship to the customer than other competitive providers can [Helander and Hirvonen 2001, pp. 281-291].

Creation and delivery of the value for the customer, being the prerequisite for a competitive edge, is especially significant with respect to system-based health care services [Grönroos 2001, pp. 240-247; Matysiewicz 2014]. 


\section{The co-creation of the value}

The notion of marketing as a facilitator and 'structurer' of the mutual creation and enjoyment of value is gaining credence. Service dominant logic is based on nine foundational propositions (FPs) [Vargo and Lusch 2004; 2008]. These FPs are not a set of "rules". Instead they represent a developing and collaborative effort to create a better marketing-grounded understanding of value and exchange. Based on an FP 6 , which stays "The customer is always a co-creator of value: There is no value until an offering is used - experience and perception are essential to value determination", the co-creation of the value is analyzed in the article [Payne et al. 2008, p. 84].

Value co-creation is seen as an interactive process, in which the both service provider and customer are involved (actors) [Grönroos 2008; Payne et al. 2008; Vargo and Lusch 2008; Macdonald et al. 2011] and considered in an inherently relational context [Vargo and Lusch 2008]. Apart of actors involved in the co-creation process, two other elements needed to be mentioned: resources and mechanisms. Consumers do not only need goods; they need to perform mental and physical resources that satisfy their needs [Vargo and Lusch 2004]. The customer has become an operant resource rather than an operand resource (target) and customers can be seen involved in the entire value chain in acting on an operand resource [Vargo and Lusch 2004]. Grönroos [2008] supports the idea that customers are the value creators and they create value for themselves in their everyday practices by applying skills held by them together with using resources provided by a company.

The service-dominant logic emphasizes also that through a set of processes and resources the service provider seeks to create value propositions [Vargo and Lusch 2004]. Processes involve mechanisms, such as activities, procedures, tasks and interactions, which support the co-creation of value [Vargo and Lusch 2004; Payne et al. 2008]. Also Grönroos [2008] sees value co-creation as a process of activities and interactions by actors involved.

In the work of Prahalad and Ramaswamy their research on co-creation embraces a holistic perspective. Their characterization of the evolution and transformation of customers from "passive audiences" to "active players" [Prahalad and Ramaswamy 2000], has particular resonance to value co-creation. Significantly, they point to the emergence of a new logic for value creation where value is embedded in personalized experiences, noting, "early experimenters are moving away from the old industry model that sees value as created from goods and services to a new model where value is created by experiences" [Prahalad and Ramaswamy 2004, p. 172].

\section{Research method and results}

The research was conducted between 2014 and 2015 by means of exploratory, case research method. The research design was qualitative and exploratory in nature. The basis for selecting the case studies was the approach applied by Collins and 
Porras [1994]. They studied "truly exceptional companies" and compared them with another set of very good companies. In every case, they put their iconic company up against a comparator, at some point, held equal stature in the same industry. Both semi-structured interviews and analysis of secondary data were used for data collection. The companies selected for the research are health care medical unites, representing the international network organization. Case A is represented by Leader, a multinational company which has been actively involved in development of a network of medical entities in Poland since 1994. Case B represents a comparative company called Specialist which has been operating on the Polish market for five years. Interviewees were senior managers within their firms, possessing international experience in international markets.

The main objective of the research was to identify and describe the role, and the scope of the co-creation value process. Leader is a network of individuals with a very secure and stable bases of operation. Relationship between network elements suggests creating a network of vertical and horizontal connection. The main objective of the operation is to increase its access to complementary resources, increase operational efficiency, growth opportunities, and access to a wider group of customers. Its important feature is the hierarchical coordination of distribution network. The network is integrated, formal and highly structured and open for new entities. Leader, in addition to the distribution network, responsible for delivering value, builds a network of its own units responsible for the enrichment and comprehensive service offerings (value creation). Relationships between them are vertical and based on the value added. Value creation system itself is well illustrated in the network, and the network itself has a relatively stable resources and processes forming a specific customer value. The units responsible for value creation are an integral part of the Leader. Relationships between units and the Leader are highly structured and formal.

The empirical findings of this study support the view that the context of value co-creation in that case is inherently relational and it consists of value network that includes actors. The actors can be seen as resource integrators, because they represent resources that is integrated for co-creating the health care service. Leader consists of cooperation of several actors of value network that needs mechanisms that support actors resource integration and ability to offer value proposition to end-customers. The mechanisms are based on agreements, and ownership.

Co-creation based on relationship among the actors leads to the model where value is created by experiences. Patients are treated as active players who can co-develop and, to some extent, personalize their relationships with the Leader, and adopt a multitude of different roles. The patient can be a customer, a consumer, a competence provider, a controller of quality, a co-producer. In the last case, this role is limited by organization and it is more focused on marketing aspects of the products. To increase the patients' involvement the Leader attaches great importance to communication processes, building long-term relationships on trust, commitment and experience is the dominant strategy of creating value for the customer in this organization. 
The second researched entity on the medical market is the Specialist. It is a network of professional individuals with a relatively unstable structure of the operation. From the goal point of view, they adopt a similar structure to the dominant design networks. However, because of intangibility of the services, the basics of its operation are different. The project approach is focused around new, innovative, highly customized methods for creating and offering services or customer contact. The advantage of the network is built based on cooperation within the network, in a situation where a single company cannot just get such a dominant position. An important feature of this network is building the structures around the customer value process. Specialist network consists of branches mainly cooperating on a contractual agreements (independent units) within certain areas of activity. The network builds horizontal relations and it is open to new elements. The relationships between units are diagonal, partly competing and partly complementary. In a formal sense, there is a core of the network. The units responsible for customer value creation are well known. As mentioned earlier the links between them are less structured and open. The network models differ significantly in the area of network organization, type of network connections, and the process of creating, communicating and delivering the customer value.

The empirical findings of this study support the view that the context of value co-creation in that case is also relational and it consists of value network that includes actors. Specialist consists of cooperation of several actors of value network. The mechanisms are based on agreements, but also on routines and unconscious behavior. Relationship among the actors leads also to the model where value is created by experiences but also very strong self-involvement. Patients are treated as active players but the Specialist is giving much more freedom to co-develop and personalize their relationships with organization. The patients are the customers, consumers, competence providers, controllers of quality, co-producers. Specialist is involving them also in some aspects of medical product building. e.g. systemic product structure. Specialist is also using interactive direct and Internet contacts with the patients to build knowledge communities. High involvement, trust and experience-based relations are basis for creating value for the customer in this organization. Nonetheless, it should be remembered that this research has some limitations. The key one is that the study refers to the choice of health care sectors, which are characterized by the highest level of customer retention and the greatest involvement on the part of consumers. In addition, the research was conducted only in Poland, which constitutes a representative model for country in transition.

\section{Conclusions}

In the health care sector, different health care providers collaborate in order to increase values for customers, such as better health state, more complex services, high quality of services, and increased feeling of safety. In the literature, value co-creation 
is seen as an interactive process, in which the both service provider and customer are involved and considered in an inherently relational context. The article presents the two case studies of international medical networks operating in Poland. They significantly are different from each other according to its size and range. Leader is a dominant private health care network on the Polish market with 20 years' experience, the Specialist is new company, with much smaller experience. The empirical findings of this study support the view that the context of value co-creation in both cases are relational and it consists of value network that includes actors and leads to the model where value is created by experiences. In both cases patients are treated as active players and are the customers, competence providers, controllers of quality, co-producers. The main difference is connected with aspects of co-creation of value. In case of the Leader it is limited to marketing elements and value for customers is standardized. Specialist involves patients into co-creation process of product itself. The value for customers is strongly individualized.

\section{Bibliography}

Allee, V., Value Network Analysis and Value Conversion of Tangible and Intangible Assets, "Journal of Intellectual Capital", vol. 9, no. 1, 2008, pp. 5-24.

Armstrong, G., Kotler, P., Marketing: An Introduction, $8^{\text {th }}$ ed., Pearson Prentice Hall, New Jersey 2007.

Bitner, M.J., Faranda, W.T., Hubbert, A.R., Zeithaml, V.A., Customer Contributions and Roles in Service Delivery, "International Journal of Service Industry Management”, vol. 8, no. 3, 1997, pp. 193-205.

Butz, H.E.J. Goodstein, L.D., Measuring Customer Value: Gaining the Strategic Advantage, “Organizational Dynamics", vol. 24, no. 3, 1996, pp. 63-77.

Collins, J.C., Porras, J.I., Built to Last: Successful Habits of Visionary Companies, $1^{\text {st }}$ ed., HarperBusiness, New York 1994.

Drucker, P.F., The Practice of Management, HarperCollier, New York 1954.

Gale, B., Zadowolenie to nie wszystko, "Marketing Serwis", no. 4, 1998.

Grönroos, Ch., A Service Perspective on Business Relationships: The Value Creation, Interaction and Marketing Interface, "Industrial Marketing Management”, vol. 40, no. 2, 2001, pp. 240-247.

Grönroos, Ch., Service Logic Revisited: Who Creates Value? And Who Co-Creates?, "European Business Review", vol. 20, no. 4, 2008, pp. 298-314.

Helander, N., Hirvonen, P., Towards Joint Value Creation Processes in Professional Services, "The TQM Magazine", vol. 13, no. 4, 2001, pp. 281-291.

Holbrook, M.B., Customer Value and Autoethnography: Subjective Personal Introspection and the Meanings of a Photograph Collection, "Journal of Business Research", vol. 58. no. 1, 2005, pp. 45-61.

Macdonald, E.K., Wilson, H., Martinez, V., Toossi, A., Assessing Value-In-Use: A Conceptual Framework and Exploratory Study, "Industrial Marketing Management”, vol. 40. no. 5, 2011, pp. 671-682.

Matysiewicz, J., Marketing organizacji sieciowych ustug profesjonalnych $w$ procesie tworzenia wartości dla klienta, Publishing House UE Katowice, Katowice, 2014.

Möller, K., Rajala, A., Rise of Strategic Nets - New Modes of Value Creation, "Industrial Marketing Management", vol. 36, no. 7, 2007, pp. 895-908.

Ojasalo, J., Quality Dynamics in Professional Services, Publications of the Swedish School of Economics and Business Administration, no. 76. Helsinki 1999.

Parolini, C., The Value Net: A Tool For Competitive Strategy, John Wiley \& Sons, UK 1999. 
Payne, A.F., Storbacka, K., Frow, P., Managing the Co-Creation of Value, "Journal of the Academy of Marketing Science", vol. 36, no. 1, 2008, pp. 83-96.

Prahalad, C.K., Ramaswamy, V., Co-Opting Customer Competence, 2000 (January).

Prahalad, C.K., Ramaswamy, V., The Future of Competition: Creating Unique Value with Customers, Harvard, Boston, MA 2004.

Rust, R.T., Oliver, R.L., Service Quality: Insights and Managerial Implications from the Frontier, [in:] Service Quality: New Directions for Theory and Practice, R.T. Rust, R.L. Oliver (eds.), Sage, Thousand Oaks 1994.

Sheth, J.N., Newman, B.I., Gross, B.L., Consumption Values and Market Choices: Theory and Applications, Southwestern Publications, 1991.

Vargo, S.L., Lusch, R.F., Evolving to a New Dominant Logic for Marketing, "Journal of Marketing”, vol. 68 , no. 1, 2004, pp. 1-17.

Vargo, S.L., Lusch, R.F., Service-Dominant Logic: Continuing the Evolution, "Journal of the Academy of Marketing Science”, vol. 36, no. 01, 2008, pp. 1-10.

Woodall, T., Conceptualizing 'Value for the Customer': An Attributional, Dispositional and Structural Analysis, “Academy of Marketing Science Review”, no. 12, 2003, http://www.amsreview.org/articles/ woodall12-2003.pdf (access: 01.02.2017).

Zeithaml, V.A., Consumer Perception of Price, Quality and Value: A Means-End Model and Synthesis of Evidence, "Journal of Marketing”, vol. 52, no. 3, 1988 (July), pp. 2-22.

\section{Value Co-Creation in Health Care Networks - International Perspective}

Creating value for customers has been recognized as a key concept in marketing, making the value and value creation an important research subject. In the article it is assumed that value for customers means that, after being assisted by the provision of resources or interactive processes, customers are or feel better off than before. Value co-creation is seen as an interactive process, in which the both service provider and customer are involved and considered in an inherently relational context. The main objective of the research was to identify and describe the role and the scope of the co-creation value process. The research included two international health care networks operating in Poland.

\section{Wspóltworzenie wartości dla pacjenta w sieciowych jednostkach medycznych - perspektywa międzynarodowa}

Współcześnie marketing w dominujący sposób związany jest z tworzeniem wartości. Ujawnia się to m.in. przez rosnące znaczenie nowych nurtów w marketingu - logiki dominacji usługi, marketingu usług (szczególnie relacyjnego marketingu usług), marketingu doświadczeń, przenikania do marketingu postulatów związanych z ideą społecznej odpowiedzialności biznesu czy w końcu różnych koncepcji zaangażowania klientów we współtworzenie wartości. Wartości w marketingu przestają być łączone bezpośrednio z produktem lub usługą w kontekście korzyści lub satysfakcji klientów, ale urzeczywistniają się w doświadczeniach klientów, co ujawnia ich personalizowany charakter. Tematyka ta nabiera szczególnego znaczenia w przypadku sektora usług medycznych. W opracowaniu podjęto próbę identyfikacji i opisu działalności marketingowej sieciowych jednostek usług profesjonalnych w kontekście procesu współtworzenia wartości dla klienta w oparciu o przeprowadzone badania empiryczne. Badaniami objęto sieciowe jednostki medyczne funkcjonujące w otoczeniu międzynarodowym. 